Review

\title{
Biosurfactants Produced by Marine Microorganisms with Therapeutic Applications
}

\author{
Eduardo J. Gudiña *, José A. Teixeira and Lígia R. Rodrigues \\ CEB-Centre of Biological Engineering, University of Minho, 4710-057 Braga, Portugal; \\ jateixeira@deb.uminho.pt (J.A.T.); lrmr@deb.uminho.pt (L.R.R.) \\ * Correspondence: egudina@deb.uminho.pt; Tel.: +351-253-601968; Fax: +351-253-604429 \\ Academic Editor: Paul Long \\ Received: 30 November 2015; Accepted: 1 February 2016; Published: 18 February 2016
}

\begin{abstract}
Marine microorganisms possess unique metabolic and physiological features and are an important source of new biomolecules, such as biosurfactants. Some of these surface-active compounds synthesized by marine microorganisms exhibit antimicrobial, anti-adhesive and anti-biofilm activity against a broad spectrum of human pathogens (including multi-drug resistant pathogens), and could be used instead of existing drugs to treat infections caused by them. In other cases, these biosurfactants show anti-cancer activity, which could be envisaged as an alternative to conventional therapies. However, marine biosurfactants have not been widely explored, mainly due to the difficulties associated with the isolation and growth of their producing microorganisms. Culture-independent techniques (metagenomics) constitute a promising approach to study the genetic resources of otherwise inaccessible marine microorganisms without the requirement of culturing them, and can contribute to the discovery of novel biosurfactants with significant biological activities. This paper reviews the most relevant biosurfactants produced by marine microorganisms with potential therapeutic applications and discusses future perspectives and opportunities to discover novel molecules from marine environments.
\end{abstract}

Keywords: biosurfactant; antimicrobial activity; anti-adhesive activity; anti-biofilm activity; anti-cancer activity; metagenomics

\section{Introduction}

A huge and extensive source of natural compounds can be retrieved from the marine environment [1,2]. Marine microorganisms exhibit unique metabolic and physiological capabilities conferring them the ability to survive in extreme conditions and consequently produce novel metabolites that cannot be found elsewhere [3,4]. Hence, the marine environment holds a great promise towards the discovery of novel bioactive and relevant compounds including antibiotics, enzymes, vitamins, drugs and biosurfactants, among others $[1,5,6]$.

Biosurfactants have attracted much attention in recent years; they are surface-active compounds synthesized by microorganisms that exhibit diverse chemical structures, including glycolipids, lipopeptides, polysaccharide-protein complexes, phospholipids, fatty acids and neutral lipids $[4,5,7]$. Due to their amphipathic nature, biosurfactants display a variety of surface activities, which allows their application in several fields related with emulsification, foaming, detergency, wetting, dispersion and solubilisation of hydrophobic compounds [8,9]. Many biosurfactants have been reported to possess a similar or better performance when compared with synthetic surfactants, which in addition to their lower toxicity, higher biodegradability and effectiveness at extreme temperatures, salinities and $\mathrm{pH}$ values, make them a green alternative to their chemical counterparts in different applications, including agriculture, food, cosmetics or petroleum industries, as well as in bioremediation [8-12]. Furthermore, 
several biosurfactants exhibit antibacterial, antifungal, antiviral or anti-tumour activities, making them potential alternatives to conventional therapeutic agents in many biomedical applications [4,7-9,13].

Biosurfactant-producing microorganisms are ubiquitous, inhabiting both water (sea, fresh water and ground water) and land (soil, sediment and sludge), as well as environments characterized by extreme conditions of $\mathrm{pH}$, temperature or salinity (e.g., hyper saline sites and oil reservoirs) [4,14-17]. Due to their unique environmental conditions, the marine environments are a good source for the isolation of new biosurfactant-producing microorganisms. A considerable number of marine microorganisms able to produce biosurfactants with different structures have been reported, as discussed below. However, it has to be taken into account that the great majority of the marine microbial diversity remains unexplored, mainly due to the difficulty of growing marine microorganisms under laboratory conditions [6,18-20].

This paper reviews the most relevant biosurfactants produced by marine microorganisms with potential therapeutic applications, and discusses future perspectives and opportunities to discover novel biosurfactants from marine environments.

\section{Biosurfactants from Marine Microorganisms: New Weapons to Fight Human Pathogens}

Most human bacterial infections can be successfully treated using current antibiotic therapies. However, in recent years, a significant increase in the emergence of pathogenic microorganisms resistant to the available antimicrobials has been observed, including multi-drug resistant (MDR) pathogens, which has been associated with the misuse or abuse of antibiotics. As a result, persistent and difficult to treat infectious diseases appeared, which constitutes a serious public health problem [21]. Furthermore, in the last decades, the discovery of new antimicrobials has declined considerably (only two new classes of antibiotics have been commercialized since 1962), due to the difficulties in identifying novel and effective compounds and the subsequent high economic investments required for their development [21]. Therefore, there is an urgent demand for novel antimicrobial drugs.

Several biosurfactants have been reported to exhibit antimicrobial activity against different human pathogens; furthermore, these compounds usually display anti-adhesive and anti-biofilm activities, making them useful to reduce the adhesion and colonization by pathogenic microorganisms, as well as to remove pre-formed biofilms [22-25]. Although biosurfactants have been extensively studied, most of them were obtained from microorganisms isolated from terrestrial samples or hydrocarbon-polluted areas, whereas biosurfactants produced by marine microorganisms have been less explored [26]. The most relevant biosurfactants produced by marine microorganisms exhibiting antimicrobial, anti-adhesive or anti-biofilm activities against different pathogenic and opportunistic microorganisms are shown in Table 1. Several of these biosurfactants are effective against a broad spectrum of human pathogens, including Gram-positive and Gram-negative bacteria, as well as the yeast Candida albicans. Furthermore, in some cases they are also effective against MDR clinical isolates. Therefore, they can be an alternative to the existing drugs to treat infections caused by those pathogens.

It should be noted that, with the exception of the isolate Serratia marcescens described by Dusane and co-workers [28], all the other microorganisms reported in Table 1 were isolated from marine samples collected in the coastal waters of India, which suggests a higher investment of this country in the exploration of the marine resources. Regarding the phylogeny of the different isolates, more than half of them are actinomycetes. Furthermore, most of those microorganisms were isolated from marine macro-organisms. Marine sponges and other marine invertebrates are important sources of novel bioactive compounds, including antimicrobial, anti-adhesive and anti-biofilm agents. These compounds play a critical role in their defence against predators, infectious agents and biofilm-forming microorganisms, and most of them are synthesized by symbiotic microorganisms and not by the host macro-organism $[28,31,37,38]$. 
Table 1. Biosurfactants produced by marine microorganisms with antimicrobial, anti-adhesive or anti-biofilm activities against human pathogens.

\begin{tabular}{|c|c|c|c|}
\hline Microorganism (Origin) & Biosurfactant Type (Structure) & Activity & Reference \\
\hline \multirow{2}{*}{$\begin{array}{l}\text { Brevibacterium casei MSA19 (marine } \\
\text { sponge Dendrilla nigra) }\end{array}$} & \multirow{2}{*}{ Glycolipid (unknown) } & $\begin{array}{l}\text { Antimicrobial activity against Escherichia coli, Klebsiella pneumoniae, } \\
\text { Proteus mirabilis, Pseudomonas aeruginosa, haemolytic Streptococcus, } \\
\text { Vibrio parahaemolyticus and Vibrio vulnificus }\end{array}$ & \multirow{2}{*}{ [27] } \\
\hline & & $\begin{array}{l}\text { Anti-biofilm activity against mixed and individual cultures of E. coli, } \\
\text { P. aeruginosa and Vibrio spp. }\end{array}$ & \\
\hline $\begin{array}{l}\text { Serratia marcescens (hard marine coral } \\
\text { Symphyllia sp.) }\end{array}$ & Glycolipid (glucose + palmitic acid) & $\begin{array}{l}\text { Antimicrobial, anti-adhesive and anti-biofilm activity against } \\
\text { Candida albicans and P. aeruginosa }\end{array}$ & [28] \\
\hline $\begin{array}{l}\text { Streptomyces sp. B3 (marine } \\
\text { sediment samples) }\end{array}$ & Glycolipid (unknown) & $\begin{array}{l}\text { Antimicrobial activity against C. albicans, E. coli, P. aeruginosa and } \\
\text { Staphylococcus aureus }\end{array}$ & [29] \\
\hline $\begin{array}{l}\text { Streptomyces sp. MAB36 (marine } \\
\text { sediment samples) }\end{array}$ & Glycolipid (unknown) & $\begin{array}{l}\text { Antimicrobial activity against Aspergillus niger, Bacillus cereus, C. albicans, } \\
\text { Enterococcus faecalis, Shigella boydii, Shigella dysenteriae and S. aureus }\end{array}$ & [30] \\
\hline $\begin{array}{l}\text { Aspergillus ustus MSF3 (marine } \\
\text { sponge Fasciospongia cavernosa) }\end{array}$ & Glycolipoprotein (unknown) & $\begin{array}{l}\text { Antimicrobial activity against C. albicans, E. faecalis, E. coli, K. pneumoniae, } \\
\text { Micrococcus luteus, P. mirabilis, P. aeruginosa, S. aureus, Staphylococcus } \\
\text { epidermidis and haemolytic Streptococcus }\end{array}$ & [31] \\
\hline \multirow[t]{2}{*}{ Bacillus circulans (seawater sample) } & \multirow[t]{2}{*}{ Lipopeptide (unknown) } & $\begin{array}{l}\text { Antimicrobial activity against Acinetobacter calcoaceticus, Citrobacter freundii, } \\
\text { Enterobacter cloacae, E. coli, Micrococcus luteus, P. mirabilis, Proteus vulgaris, } \\
\text { Serratia marcescens and multi-drug resistant E. coli }{ }^{a}, \text { K. pneumoniae }{ }^{b} \text { and } \\
\text { S. aureus }{ }^{c}\end{array}$ & \multirow[t]{2}{*}[32,33]{} \\
\hline & & $\begin{array}{l}\text { Anti-adhesive and anti-biofilm activities against C. freundii, E. coli, P. vulgaris, } \\
\text { Salmonella typhimurium and S. marcescens }\end{array}$ & \\
\hline $\begin{array}{l}\text { Bacillus circulans DMS-2 } \\
\text { (marine samples) }\end{array}$ & $\begin{array}{l}\text { Lipopeptide (Mixture of three different Fengycins: } \beta \text {-hydroxy } \\
\text { fatty acid of } 15,16 \text { or } 17 \text { carbons + cyclic decapeptide) }\end{array}$ & Antimicrobial activity against $C$. freundii, E. coli, P. vulgaris and S. marcescens & [34] \\
\hline $\begin{array}{l}\text { Bacillus licheniformis NIOT-AMKV06 } \\
\text { (marine sponge Acanthella sp.) }\end{array}$ & Lipopeptide (unknown) & $\begin{array}{l}\text { Antimicrobial activity against E. faecalis, K. pneumoniae, M. luteus, P. mirabilis, } \\
\text { Salmonella typhi, Shigella flexineri, S. aureus and Vibrio cholera }\end{array}$ & [35] \\
\hline $\begin{array}{l}\text { Brevibacterium aureum MSA13 } \\
\text { (marine sponge Dendrilla nigra) }\end{array}$ & $\begin{array}{l}\text { Lipopeptide (Brevifactin: Octadecanoic acid methyl } \\
\text { ester + pro-leu-gly-gly) }\end{array}$ & $\begin{array}{l}\text { Antimicrobial activity against C. albicans, E. coli, K. pneumoniae, M. luteus, } \\
\text { P. mirabilis, P. aeruginosa, S. aureus, S. epidermidis and haemolytic Streptococcus }\end{array}$ & [36] \\
\hline $\begin{array}{l}\text { Nocardiopsis alba MSA10 (marine } \\
\text { sponge Fasciospongia cavernosa) }\end{array}$ & Lipopeptide (unknown) & $\begin{array}{l}\text { Antimicrobial activity against C. albicans, E. faecalis, K. pneumoniae, M. luteus, } \\
\text { P. mirabilis, S. aureus and S. epidermidis }\end{array}$ & [37] \\
\hline $\begin{array}{l}\text { Nocardiopsis dassonvillei MAD08 } \\
\text { (marine sponge Dendrilla nigra) }\end{array}$ & Unknown & 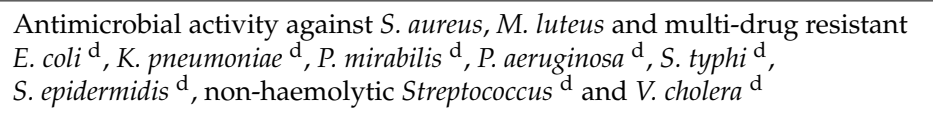 & [38] \\
\hline
\end{tabular}

${ }^{a}$ resistant to ciprofloxacin, ofloxacin, levofloxacin, streptomycin, penicillin, ceftazidine, norfloxacin and ofloxacin; ${ }^{b}$ resistant to ceftriaxone, ciprofloxacin, ofloxacin, levofloxacin norfloxacin, piperacillin, tazobactam, streptomycin and penicillin; ${ }^{\mathrm{c}}$ resistant to methicillin and streptomycin; ${ }^{\mathrm{d}}$ resistant to chloramphenicol, streptomycin, oxytetracycline, ampicillin and erythromycin. 
In most of the above referred studies, the biosurfactants were only partially characterized and their activities were studied using the crude extracts rather than purified molecules. However, in other cases a more complete chemical characterization was performed. Regarding the lipopeptide biosurfactant produced by the Bacillus circulans strain reported by Das et al. [32], six different fractions were obtained from the crude extract using reverse phase HPLC, and only one of them was responsible for the antimicrobial activity exhibited by the crude biosurfactant. It should be pointed out that, contrary to other lipopeptide biosurfactants such as surfactin, this biosurfactant did not show haemolytic activity, which could facilitate its use as a therapeutic agent [32]. Similarly, the lipopeptide biosurfactant produced by B. circulans DMS-2 was identified as a mixture of different fengycin isoforms (including $\mathrm{C}_{15^{-}}, \mathrm{C}_{16^{-}}$and $\mathrm{C}_{17^{-}}$-fengycin). Four different surface-active fractions were resolved and purified through HPLC, and only one of them (containing $\mathrm{C}_{16^{-}}$and $\mathrm{C}_{17}$-fengycin) was responsible for the antimicrobial activity observed in the crude biosurfactant [34].

Additionally, several biosurfactants reported in Table 1 displayed a similar or better performance when compared with conventional antibiotics. In order to compare the antimicrobial activity exhibited by different compounds, the minimum inhibitory concentration (MIC) and minimum bactericidal concentration (MBC) are commonly used parameters. The MIC for an antimicrobial compound against a specific microorganism is the minimum concentration of that compound that completely inhibits the growth of that microorganism. The MBC is the minimum concentration of that compound that is lethal for that microorganism. One of the HPLC-purified fractions of the lipopeptide biosurfactant produced by B. circulans showed lower MICs and MBCs against S. marcescens, Proteus vulgaris and Enterobacter cloacae (between 10 and $60 \mu \mathrm{g} \cdot \mathrm{mL}^{-1}$ ) when compared with the conventional antibiotics penicillin and streptomycin (between 40 and $900 \mu \mathrm{g} \cdot \mathrm{mL}^{-1}$ ). Regarding the MDR Escherichia coli, Klebsiella pneumoniae and Staphylococcus aureus (which were resistant to penicillin and streptomycin at concentrations up to $1000 \mu \mathrm{g} \cdot \mathrm{mL}^{-1}$ ), MICs and MBCs between 60 and $800 \mu \mathrm{g} \cdot \mathrm{mL}^{-1}$ and $200-1000 \mu \mathrm{g} \cdot \mathrm{mL}^{-1}$, respectively, were obtained for this biosurfactant [32]. The glycolipid biosurfactant produced by Streptomyces sp. MAB36 possessed a similar inhibitory activity against Aspergillus niger and C. albicans to the conventional antifungal nystatin [30]. The biosurfactant produced by Nocardiopsis dassonvillei MAD08 was more effective against E. coli and Staphylococcus epidermidis than chloramphenicol [38]. Finally, the biosurfactant produced by $S$. marcescens exhibited a higher inhibitory effect against $C$. albicans and Pseudomonas aeruginosa as compared to the conventional antimicrobials fluconazole and streptomycin, respectively [28].

In addition, some of these biosurfactants displayed a considerable anti-adhesive and anti-biofilm activity. The biosurfactant produced by $B$. circulans (partially purified through gel filtration chromatography) exhibited anti-adhesive activity at concentrations between 0.1 and $10 \mathrm{mg} \cdot \mathrm{mL}^{-1}$. At the highest concentration tested $\left(10 \mathrm{mg} \cdot \mathrm{mL}^{-1}\right)$, microbial adhesion was inhibited between $84 \%$ and $89 \%$, and pre-formed biofilms were removed (with efficiencies between $59 \%$ and $94 \%$ ) for all the pathogenic microorganisms tested [33]. The glycolipid biosurfactant produced by Brevibacterium casei MSA19 (partially purified through thin layer chromatography) removed pre-formed biofilms of all the pathogenic microorganisms tested at $30 \mu \mathrm{g} \cdot \mathrm{mL}^{-1}$ [27].

Despite their potential applications, the widespread use of biosurfactants is still limited by their low productivities. The optimization of the culture medium and cultivation conditions can greatly contribute to increase their production yields [31,37]. Furthermore, the composition of the culture medium can alter the structure and activity of the biosurfactant. In the case of the isolate B. circulans, the antimicrobial activity of the biosurfactant was dependent on the carbon source used, due to the production of different isoforms in the different media; the biosurfactant produced using culture media containing glycerol, starch or sucrose exhibited a higher antimicrobial activity when compared with the one produced in a medium containing glucose [39]. However, in the case of marine microorganisms, which are adapted to the marine environment conditions, their cultivation in the laboratory or in industrial fermenters can be difficult. One alternative is to produce those biosurfactants in heterologous hosts. In the case of the lipopeptide biosurfactant produced by Bacillus licheniformis NIOT-AMKV06, 
three genes involved in its biosynthesis ( $s f p, s f p O$, and $s r f A$ ) were cloned and expressed in E. coli. As a result, biosurfactant production was increased from $3 \mathrm{~g} \cdot \mathrm{L}^{-1}$ up to $11.7 \mathrm{~g} \cdot \mathrm{L}^{-1}$ [35].

Although not included in Table 1, the strain Streptomyces sp. ISP2-49E, isolated from marine sediment samples obtained from Galveston Bay (Texas) must be mentioned. This isolate produced the rhamnolipid biosurfactant L-rhamnosyl-L-rhamnosyl- $\beta$-hydroxydecanoyl- $\beta$-hydroxydecanoate (Rha-Rha- $\mathrm{C}_{10}-\mathrm{C}_{10}$ ), being the first report on a rhamnolipid-producing Streptomyces strain [15]. Although the properties of the biosurfactant synthesized by this isolate were not studied in detail, rhamnolipids have been reported to possess a broad spectrum of antimicrobial and anti-adhesive activities [22,23]. However, the main rhamnolipid producers are P. aeruginosa strains, an opportunistic human pathogen. Therefore, the use of alternative non-pathogenic rhamnolipid producers can contribute to the safe use of rhamnolipids as therapeutic agents. That can be achieved using either non-pathogenic natural rhamnolipid-producing strains [15,40-42], or engineered non-pathogenic hosts expressing the genes required for the synthesis of rhamnolipids [43,44].

The antagonistic activities exhibited by these biosurfactants against human pathogens (including MDR pathogens) make them candidates to be used as an alternative to traditional antibiotics. However, despite their great potential, none of these compounds is yet being used for the treatment of human infections.

\section{Biosurfactants from Marine Microorganisms: Alternative Anti-Cancer Agents}

Cancer represents an extremely important health risk affecting millions of people worldwide [45]; hence, any progress leading to enhanced survival is a global priority. Given its unpredictable nature, cancer is a major concern for human health. Several strategies have been pursued over the years, whether searching for new biomarkers, treatments or drugs. However, despite these efforts, a successful targeted selective and non-toxic therapy is still to be developed. Traditional cancer chemotherapy has mainly been based on using highly cytotoxic drugs that non-specifically target any dividing cells; this may result in a modest improvement in patient survival, thus overall prognosis of most patients remains dismal and treatment is non-specific, non-selective and toxic. In this sense, the search and development of new anti-cancer drugs that can overcome the multi-drug resistance of cancer cells remains a great challenge. Currently, many anti-cancer drugs used in clinical practice are natural products or derivatives thereof [46-49]. For that reason, it is likely that the continued and systematic exploration of natural sources, such as the marine microbiota, will lead to different and unforeseen compounds with interesting biological activities, including anti-cancer activity [50,51]. The microbial production of anti-cancer drugs is advantageous compared to their extraction from natural sources such as plants, namely the possibility of genetically engineering microbes for a given purpose, as well as their higher production rates [52]. As previously mentioned, biosurfactants are among those microbial compounds exhibiting promising biological activities [53].

Biosurfactants, in particular lipopeptides and glycolipids, have been highlighted for their potential to be used as anti-cancer agents interfering with cancer progression processes (Figure 1) [7]. These compounds have been implicated in several intercellular molecular recognition steps comprising signal transduction, cell differentiation and cell immune response, among others [24]. In addition, they exhibit low toxicity, high efficacy and easy biodegradability, which are relevant features in any anti-cancer agent. Different mechanisms underlying the anti-cancer activity of biosurfactants have been proposed including the delay of cell cycle progression; inhibition of crucial signalling pathways such as Akt, extracellular signal-regulated kinase/c-Jun N-terminal kinase (ERK/JNK) and Janus kinase/signal transducer and activator of transcription (JAK/STAT); reduction of angiogenesis; activation of natural killer T (NKT) cells; and induction of apoptosis through death receptors in cancer cells. In addition, the ability of biosurfactants to disrupt cell membranes, leading to a sequence of events that include lysis, increased membrane permeability and metabolite leakage, has also been pointed as a probable mechanism of anti-cancer activity [54]. 


\section{Biosurfactants}

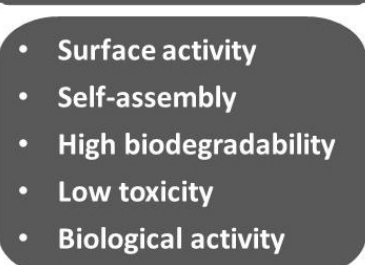

- Inhibition of PI3K/Akt pathway - Inhibition of MAPK signalling

- Activation of caspase

- Inhibition of JAK/STAT pathway

- Inhibition of MMP-2/9

- Activation of invariant NKT cells

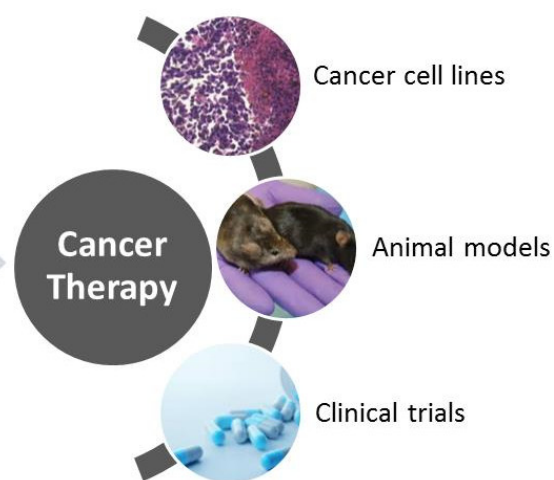

Figure 1. Properties and anti-cancer effects of biosurfactants towards the design of novel cancer therapies.

Despite this exciting potential and the great diversity of chemical structures that can be found among biosurfactants, the majority of the studies on their anti-cancer activity have been conducted with few well-known molecules produced by microbes mainly isolated from terrestrial sources. Therefore, other natural environments, such as the marine microbiota, open up a great opportunity to discover new biosurfactants exhibiting distinct chemical structures and powerful anti-cancer activities provided by different mechanisms of action and/or different targets.

Lipopeptides, particularly surfactin, have been widely studied for their potential anti-cancer activity against a number of cancer cell lines $[7,53,55]$. The anti-cancer activity of surfactin has been related with the hydrophobic nature of the fatty acid moiety that interacts with the acyl chain of membrane-bound phospholipids [56]. Simultaneously, its peptide moiety strongly interacts with the polar heads of the membrane lipids in cancer cells. Surfactin, holding a longer fatty acid chain, penetrates more efficiently into the cancer cell membrane [56]. Different mechanisms have been suggested for its anti-cancer activity depending on the cancer models evaluated (breast, colon, leukaemia, hepatic, melanoma) [7] including the inhibition of matrix metalloproteinases (protease enzymes involved in invasion and metastasis processes) [57]; PI3/Akt and MAPK signalling pathways [56]; cell cycle arrest at G2/M [58]; and induction of apoptosis via ROS/JNK-mediated mitochondrial/caspase pathway [59]. This cyclic lipopeptide comprised by seven amino acids and a lipid moiety (containing 13 to 15 carbons) is produced by several strains of bacilli retrieved from different sources, including the marine environment $[7,53,60]$. The marine bacterium $B$. circulans DMS-2 was found to produce lipopeptides, namely surfactin and fengycin isoforms, displaying a significant and selective anti-proliferative activity against the human colon cancer cell lines HCT-15 $\left(\mathrm{IC}_{50} 80 \mu \mathrm{g} \cdot \mathrm{mL}^{-1}\right)$ and HT-29 $\left(\mathrm{IC}_{50} 120 \mu \mathrm{g} \cdot \mathrm{mL}^{-1}\right)$ [55].

In addition, different bacilli strains produce iturins (bacillomycins, iturin $\mathrm{A} / \mathrm{C}$ and mycosubtilins). These lipopeptides are amphiphilic molecules containing a cyclic peptide chain conjugated with a $\beta$-amino fatty acid (containing 13 to 17 carbons). Iturin A, produced by a marine Bacillus megaterium strain, was found to significantly impair proliferation and inhibit the Akt signalling network leading to apoptosis induction in breast cancer cells (MDA-MB-231 and MCF-7). It is important to note that treatments that can inhibit breast cancer types exhibiting aberrant Akt activity are of utmost importance. Additionally, this biosurfactant inhibited EGF induced Akt phosphorylation and its downstream targets GSK3 $\beta$ and FoxO3 $\alpha$. Iturin A was also found to inhibit tumour growth in a breast cancer xenograft model [61]. Other biosurfactants produced by marine microorganisms have been reported among the iturin class, such as hallobacillin [62] and mixirins [63]. Hallobacillin, produced by a Bacillus sp. isolated from marine sediments near the Guaymas Basin (Mexico), is cytotoxic against the human colon cancer cell line HCT-116 ( $\mathrm{IC}_{50} 0.98 \mu \mathrm{g} \cdot \mathrm{mL}^{-1}$ ) [63]. Mixirins (A, B and C), also isolated from a marine Bacillus sp. strain, are cyclic octapeptides comprised by a mixture of L- and D-amino 
acid with an unusual $\beta$-amino alkanoic acid. Likewise, these lipopeptides were cytotoxic against colon cancer cells, being the variant A the most potent [63].

It is clear that the marine environment represents a promising source of novel added value compounds. Among these compounds, some new biosurfactant structures have been reported, namely somocystinamide A [64], fellutamides [65-67], rakicidin [68-72] and apratoxin [73-77].

Wrasidlo and collaborators [78] obtained the lipopeptide somocystinamide A from the cyanobacteria Lyngbya majuscula. This biosurfactant exhibited significant cytotoxicity against leukaemia, lung, breast and prostate cancer cells with $\mathrm{IC}_{50}$ values ranging from $1.3 \mu \mathrm{M}$ to $970 \mathrm{nM}$ depending on the cancer model. It is considered a pluripotent inhibitor of angiogenesis and tumour cell proliferation. Moreover, it induced apoptosis in Jurkat and leukaemia cells through caspase- 8 activation and PARP cleavage. Somocystinamide A was also found to effectively block endothelial cell tube formation in vitro and blood vessel growth in a zebrafish model, thus suggesting its anti-angiogenic character.

Fellutamides A and B are linear lipopeptides isolated from the fish-derived fungus Penicillium fellutanum. These biosurfactants were found to be cytotoxic against P388, L1210 murine leukaemia cells and KB human epidermoid carcinoma cells [67]. Fellutamides $C$ and F, isolated from the sponge-derived fungus Aspergillus versicolor, displayed cytotoxic effects against SK-MEL-2 skin cancer, XF498 CNC cancer, HCT-15 colon cancer, A549 lung cancer and SK-OV-3 ovarian cancer cell lines, with $\mathrm{IC}_{50}$ values ranging from 3.1 to $33.1 \mu \mathrm{M}$ for fellutamide $\mathrm{C}$, and between 0.2 and $3.1 \mu \mathrm{M}$ for fellutamide F $[65,66]$.

Rakicidins are anti-cancer lipopeptides produced by the marine bacterium Micromonospora [69,70]. Among these lipopeptides, rakicidin A exhibits a unique hypoxia-selective cytotoxicity against several cancer cell lines, such as HCT-8 and PANC-1 [72]. Hypoxia is present mainly in solid tumours and is associated with a poor prognosis and clinical outcome since it triggers invasiveness, angiogenesis, metastasis and apoptosis evasion [72]. Rakicidin B has also been reported to be active against oesophageal squamous carcinoma cells (EC109), lung cancer cells (A549 and 95D), gastric cancer cells (SGC7901), uterine cervix cancer cells (HeLa) and hepatocellular carcinoma cells (HepG2) [70]. This rakicidin derivative induced apoptosis through the activation of caspase-3, -7 and -9 , and blocked MAPK and JNK/p38 signalling pathways. Rakicidin derivatives C and D containing short lipid chains were non cytotoxic [68], although the derivative D was found to interfere with the invasiveness of aggressive breast cancer cells [68].

Apratoxins (derivatives $A$ to $G$ ) are a new group of cyclic lipopeptides isolated from marine cyanobacteria [74] that exhibit a significant cytotoxicity against a number of cancer cells. Apratoxin A induced apoptosis through caspases activation and inhibited the IL-6 signalling pathway in human bone osteosarcoma U2OS cells. Two apratoxin analogues (apratoxin A sulfoxide and apratoxin $\mathrm{H}$ ) isolated from the cyanobacterium Moorea producens showed a great cytotoxicity on human NCI-H460 lung cancer cells [76]. Other research groups also reported strong cytotoxicity against this cell line using other apratoxin derivatives (D, F and G) [75]. Apratoxin E, F and $G$ were also active against HCT-116 colon cancer cells and in a mouse model [77].

Glycolipids have also been shown to be involved in growth arrest and apoptosis of several cancer cells $[7,79]$. Some glycolipids obtained from marine sponges have been reported, such as $\alpha$-galacosylceramide (KRN7000) [80-83], myrmekioside or trikentroside [84]. KRN7000 is a glycolipid containing a sugar moiety connected to a fatty acid chain and a sphingosine base that exhibited anti-cancer activity against liver, lung, EL-4 lymphoma, colon 26 adenocarcinoma, EL-4T cell lymphoma and sarcoma [80,82]. KRN7000 was shown to activate invariant natural killer T cells and subsequent production of interferon (IFN)-g, IL-4 and other cytokines in a dose-dependent manner [81]. Moreover, this glycolipid was found to have an inhibitory effect in advanced cancer patients with hepatitis B or C infection [83]. Myrmekioside is a glycolipid produced by the marine sponge Myrmekioderma dendyi. Its derivatives (E-1, E-2 and E-3) exhibited anti-cancer activity against two human non-small-cell lung cancer cells (NSCLC-N6 and A549) [84]. The related glycolipid, 
trikentroside, isolated from the sponge Trikentrion, also inhibited the proliferation of human non-small lung cancer A549 cells [84].

Many biosurfactant chemical structures and anti-cancer activities derived from the marine environment are still to be discovered opening up fascinating opportunities of further developments that certainly will benefit mankind.

\section{New Perspectives for the Discovery of Novel Therapeutics}

Oceans, which cover more than $70 \%$ of the Earth's surface, are one of the richest sources of potentially new bioactive compounds in the world. It is estimated that they contain up to $10^{6}$ to $10^{9}$ microbial cells per millilitre of water. As previously mentioned, microbial communities inhabiting marine environments are usually exposed to extreme conditions such as low or high temperatures $\left(0\right.$ to $100{ }^{\circ} \mathrm{C}$ ), high pressures (up to $100 \mathrm{MPa}$ ) and low nutrient availability. Their adaption to a broad variety of conditions led to the development of different survival strategies and unique biochemical, metabolic and physiological features, stemming from their wide microbial diversity. Furthermore, as the environmental conditions of marine ecosystems are very different from terrestrial ones, it is expected that marine microorganisms produce compounds with new properties and biological activities comparing to those produced by microbes of terrestrial origin [26,85-87].

In the last years, there has been an increasing interest in the study and exploration of marine microorganisms as a source of new compounds for application in different fields. For instance, several biosurfactants with pharmaceutical and medical relevance have been obtained from microorganisms isolated from marine environments, as mentioned in the sections above. However, the recent use of molecular techniques to study the diversity of marine ecosystems revealed that most of the marine microbial world remains unexplored, particularly due to the difficult of growing most of those microorganisms under laboratory conditions [26,85,86]. Culture-independent techniques (metagenomics) are a promising way to study the genetic resources of otherwise inaccessible marine microorganisms, and discover previously unknown natural compounds with important biological activities, without the requirement of culturing them. Metagenomics is a collection of molecular techniques that allow the culture-independent study of microbial communities from any environmental sample through the direct extraction and study of their genetic material, giving access to the total genetic pool and biosynthetic capacity of all the microorganisms present in that community $[86,88]$.

Metagenomic studies usually start with the extraction of the DNA from the environmental sample under study (in the case of marine ecosystems, it can be seawater, marine sediments or marine macro-organisms), although they can be based also on RNA. The DNA sample must represent (both qualitatively and quantitatively) all the microbial species present in the community. The next step is the construction of metagenomic libraries, using suitable cloning vectors. Different vectors can be used, depending on the size of the DNA fragments obtained: plasmids (which can incorporate DNA inserts up to $15 \mathrm{~kb}$ ); cosmids and fosmids (between 15 and $45 \mathrm{~kb}$ ); and bacterial artificial chromosomes (up to $100-200 \mathrm{~kb}$ ). Subsequently, the metagenomic library is transferred to a suitable host strain, usually E. coli. Finally, the individual recombinant clones are screened. The screening process can be based on the sequences of the DNA inserts cloned (sequence-based metagenomics), or in the functions that those DNA inserts confer to the host (function-based metagenomics) $[85,87,88]$.

The sequence-based metagenomics can be performed through large-scale random sequencing of metagenomic libraries, which generates a high amount of sequences. Those sequences are subsequently analysed using bioinformatics tools and are compared with sequences deposited in the databases through homology-based searches. Some of those sequences can correspond to novel genes with unknown functions. The development of next-generation sequencing technologies in recent years, as well as the subsequent significant reduction of DNA sequencing costs led to considerable progress in sequence-based metagenomics, allowing its widespread use. On the other hand, sequence-based metagenomics can be performed based on the sequence similarity, using Polymerase Chain Reaction (PCR) or DNA hybridization techniques. In this case, once selected the target genes (or proteins), 
PCR primers or DNA probes are designed according to consensus sequences specific to the most conserved regions of those genes (or proteins), and these are further used to screen the metagenomic library. The main drawback of this approach is that it requires a previous knowledge of the sequences of the genes, which naturally limits the discovery of new functions or activities [26,85]. For instance, in the specific case of biosurfactants, this approach can be used to search for new genes involved in their biosynthesis based on the sequences of already known genes. As a result, the new biosurfactants found are expected to be similar to those previously reported. However, in some cases, those genes can show slight modifications that can lead to the production of biosurfactants with different properties and activities.

On the contrary, function-based metagenomics consists in screening metagenomic libraries for the presence of activities or phenotypes resulting from the heterologous expression of the genes present in the microbial community. The main advantage of this approach is that it is not dependent on the previous knowledge of the DNA sequences; consequently, it is the best way to identify new genes and gene families encoding novel biomolecules that could not be detected using the sequence-based approaches from comparisons with previously described genes. However, function-based metagenomics entails several difficulties and challenges. Its success is dependent on the expression of the foreign genes in the heterologous host used. The most common host used for the construction of metagenomic libraries is E. coli. However, it does not guarantee the expression of all the genes existent in the microbial community under study, due to problems associated with the recognition of promoters from different taxonomic groups by the transcriptional machinery of $E$. coli, or differences in the codon usage preferences. Some examples of functional screening of metagenomic libraries for new antimicrobial compounds using E. coli and other alternative hosts simultaneously (Bacillus subtilis, Ralstonia metallidurans or Streptomyces lividans) resulted in the detection of antimicrobial activities in the alternative hosts, but not in E. coli [89-91]. For that reason, there is a growing tendency to use various hosts simultaneously with the objective of expressing most of the genes present in the microbial community. In this case, the use of broad-host range vectors is necessary to construct the metagenomic libraries. Furthermore, if a function is encoded by several genes grouped in one operon, only if the complete operon is cloned in a single DNA insert could it be detected. For instance, the genes involved in the biosynthesis of lipopeptide biosurfactants (e.g., surfactin, lichenysin, fengycin or iturin), are grouped in operons ranging from 25 to $40 \mathrm{~kb}$ in size [92]. This means that the vectors used to construct the metagenomic libraries to identify new biosurfactants must be able to incorporate DNA inserts larger than 20 to $30 \mathrm{~kb}$. Another problem is that, even if the corresponding gene is correctly expressed, if the resulting product is not excreted, it would not be detected during the screening processes. These difficulties are not applicable to the sequence-based metagenomics, where the expression of the DNA inserts is not necessary.

Furthermore, function-based metagenomics requires the development of adequate screening methods that must be sensitive and, at the same time, applicable to thousands of transformants, as metagenomic libraries with sufficient coverage of the whole community require an extremely large number of clones. It can be performed by heterologous complementation of host strains or mutants by target genes to allow their growth under selective conditions, or to allow the use of a specific substrate; or using chromogenic or fluorescent substrates to detect specific enzymatic activities [85-87]. For the identification of new antimicrobial compounds, it can be performed by screening clones for antimicrobial activity against clinically relevant microorganisms.

Despite all these issues, there are several examples of new bioactive compounds (mainly enzymes) obtained from marine samples through the application of function-based metagenomics (as reviewed by Felczykowska et al. [85] and Kennedy et al. [86]). Also, new antimicrobials have been discovered through functional screening of soil metagenomic libraries (as reviewed by Coughlan and co-workers [88]). However, to date there are no reports on the discovery of new biosurfactants using function-based metagenomics, which can be due to the difficulty of establishing an appropriate screening method. Measuring the surface tension or the emulsifying activity is not feasible to screen 
thousands of transformants. Other techniques commonly used to screen biosurfactant-producing microorganisms, such as oil spreading or the drop collapse assays, can show poor efficiency when applied on a large scale. Furthermore, all these techniques require growing the transformants in liquid medium to evaluate the production of biosurfactants. Several colorimetric techniques can be applied to detect biosurfactants on agar plates, but they are directed to specific biosurfactants, thus they are not useful to identify new compounds. One of these methods uses bromothymol blue (colour indicator) and cetylpyridinium chloride (mediator), which change from yellow-green to dark green or bright blue in the presence of different concentrations of surfactin; it has been successfully used to identify surfactin-hyperproducing B. subtilis strains [93]. The cetyltrimethylammonium bromide (CTAB) agar plate method is a semi-quantitative assay for the detection of extracellular anionic biosurfactants. In this case, the potential biosurfactant-producing clones are grown in agar plates containing the cationic surfactant CTAB and the basic dye methylene blue. Biosurfactant-producing colonies are surrounded by dark blue halos due to the formation of an insoluble ion pair between the anionic biosurfactant, CTAB and methylene blue [94]. However, it is not clear if these techniques can be useful to identify new biosurfactants. A more interesting option could be the atomized oil assay described by Burch et al. [95], which can be applied directly on agar plates. It consists in applying a fine mist of oil droplets onto the plate (where the transformants have been grown previously) using an airbrush. Biosurfactant production can be detected instantaneously due to the formation of halos around biosurfactant-producing colonies. This technique can detect low concentrations of different chemical surfactants and biosurfactants (including glycolipids and lipopeptides) and is more sensitive than the drop collapse assay [95], thus it could be a good method to screen metagenomic libraries for novel biosurfactants.

\section{Conclusions}

In recent years, there has been an increasing interest in the study and exploration of marine microorganisms as potential producers of new compounds for application in different areas, as the marine environment represents a promising source of novel bioactive compounds. Biosurfactants of marine origin, although less explored than their terrestrial counterparts, exhibit some properties that make them useful and powerful for several therapeutic applications, as alternatives to the existing drugs. However, the difficulty of isolating and growing these marine microorganisms means that most of the marine microbial world remains unexplored. Function-based metagenomics, while exhibiting several limitations, constitutes a promising approach to study the genetic resources of otherwise inaccessible marine microorganisms, giving access to the total genetic pool and biosynthetic capacity of all the microorganisms in a community, as well as allowing the discovery of novel biosurfactants.

Acknowledgments: This study was supported by the Portuguese Foundation for Science and Technology (FCT) under the scope of the strategic funding of UID/BIO/04469/2013 unit and COMPETE 2020 (POCI-01-0145-FEDER-006684). The authors also thank the FCT for the financial support under the scope of the Project RECI/BBB-EBI/0179/2012 (FCOMP-01-0124-FEDER-027462). E.J. Gudiña was supported by the Post-Doctoral fellowship CEB-BPD/01/2015/07 from the project UID/BIO/04469/2013, financed by FCT.

Author Contributions: All the authors have contributed to the work by participating in reviewing the literature, designing and writing the manuscript.

Conflicts of Interest: The authors declare no conflict of interest.

\section{References}

1. Bhatnagar, I.; Kim, S.K. Immense essence of excellence: Marine microbial bioactive compounds. Mar. Drugs 2010, 8, 2673-2701. [CrossRef] [PubMed]

2. Nuñez, R.; Garateix, A.; Laguna, A.; Fernández, M.D.; Ortiz, E.; Llanio, M.; Valdés, O.; Rodríguez, A.; Menéndez, R. Caribbean marine biodiversity as a source of new compounds of biomedical interest and other industrial applications. Pharmacologyonline 2006, 3, 111-119. 
3. Carvalho, C.C.; Fernandes, P. Production of metabolites as bacterial responses to the marine environment. Mar. Drugs 2010, 8, 705-727. [CrossRef] [PubMed]

4. Satpute, S.K.; Banat, I.M.; Dhakephalkar, P.K.; Banpurkar, A.G.; Chopade, B.A. Biosurfactants, bioemulsifiers and exopolysaccharides from marine microorganisms. Biotechnol. Adv. 2010, 28, 436-450. [CrossRef] [PubMed]

5. Shekhar, S.; Sundaramanickam, A.; Balasubramanian, T. Biosurfactant producing microbes and their potential applications: A review. Crit. Rev. Environ. Sci. Technol. 2015, 45, 1522-1554. [CrossRef]

6. Ramiah, N. Facets and opportunities. In Marine Microbiology; Ramaiah, N., Ed.; National Institute of Oceanography: Goa, India, 2005; pp. 1-6.

7. Gudiña, E.J.; Rangarajan, V.; Sen, R.; Rodrigues, L.R. Potential therapeutic applications of biosurfactants. Trends Pharmacol. Sci. 2013, 34, 667-675. [CrossRef] [PubMed]

8. Marchant, R.; Banat, I.M. Microbial biosurfactants: Challenges and opportunities for future exploitation. Trends Biotechnol. 2012, 30, 558-565. [CrossRef] [PubMed]

9. Banat, I.M.; Makkar, R.S.; Cameotra, S.S. Potential commercial applications of microbial surfactants. Appl. Microbiol. Biotechnol. 2000, 53, 495-508. [CrossRef] [PubMed]

10. Edwards, K.R.; Lepo, J.E.; Lewis, M.A. Toxicity comparison of biosurfactants and synthetic surfactants used in oil spill remediation to two estuarine species. Mar. Pollut. Bull. 2003, 46, 1309-1316. [CrossRef]

11. Poremba, K.; Gunkel, W.; Lang, S.; Wagner, F. Toxicity testing of synthetic and biogenic surfactants on marine microorganisms. Environ. Toxicol. Water Qual. 1991, 6, 157-163. [CrossRef]

12. Poremba, K.; Gunkel, W.; Lang, S.; Wagner, F. Marine biosurfactants, III. Toxicity testing with marine microorganisms and comparison with synthetic detergents. Z. Naturforsch. C 1991, 46, 210-216. [PubMed]

13. Fracchia, L.; Cavallo, M.; Martinotti, M.G.; Banat, I.M. Biosurfactants and bioemulsifiers biomedical and related applications: Present status and future potentials. In Biomedical Science, Engineering and Technology; Ghista, D.N., Ed.; InTech: Rijeka, Croatia, 2012; pp. 325-370.

14. Ibacache-Quiroga, C.; Ojeda, J.; Espinoza-Vergara, G.; Olivero, P.; Cuellar, M.; Dinamarca, M.A. The hydrocarbon-degrading marine bacterium Cobetia sp. strain MM1IDA2H-1 produces a biosurfactant that interferes with quorum sensing of fish pathogens by signal hijacking. Microb. Biotechnol. 2013, 6, 394-405. [CrossRef] [PubMed]

15. Yan, X.; Sims, J.; Wang, B.; Hamann, M.T. Marine actinomycete Streptomyces sp. ISP2-49E, a new source of rhamnolipid. Biochem. Syst. Ecol. 2014, 55, 292-295. [CrossRef] [PubMed]

16. Abraham, W.R.; Meyer, H.; Yakimov, M. Novel glycine containing glucolipids from the alkane using bacterium Alcanivorax borkumensis. Biochim. Biophys. Acta 1998, 1393, 57-62. [CrossRef]

17. Banat, I.M. The isolation of a thermophilic biosurfactant producing Bacillus sp. Biotechnol. Lett. 1993, 15, 591-594. [CrossRef]

18. Hamed, S.B.; Smii, L.; Ghram, A.; Maaroufi, A. Screening of potential biosurfactant-producing bacteria isolated from seawater biofilm. Afr. J. Biotechnol. 2012, 11, 14153-14158.

19. Harayama, S.; Kasai, Y.; Hara, A. Microbial communities in oil-contaminated seawater. Curr. Opin. Biotechnol. 2004, 15, 205-214. [CrossRef] [PubMed]

20. Stein, J.L.; Marsh, T.L.; Wu, K.Y.; Shizuya, H.; DeLong, E.F. Characterization of uncultivated prokaryotes: Isolation and analysis of a 40-kilobase-pair genome fragment from a planktonic marine archaeon. J. Bacteriol. 1996, 178, 591-599. [PubMed]

21. Coates, A.R.M.; Halls, G.; Hu, Y. Novel classes of antibiotics or more of the same? Br. J. Pharmacol. 2011, 163, 184-194. [CrossRef] [PubMed]

22. Benincasa, M.; Abalos, A.; Oliveira, I.; Manresa, A. Chemical structure, surface properties and biological activities of biosurfactant produced by Pseudomonas aeruginosa LBI from soapstock. Antonie Van Leeuwenhoek 2004, 85, 1-8. [CrossRef] [PubMed]

23. Haba, E.; Pinazo, A.; Jauregui, O.; Espuny, M.J.; Infante, M.R.; Manresa, A. Physicochemical characterization and antimicrobial properties of rhamnolipids produced by Pseudomonas aeruginosa 47T2 NCBIM 40044. Biotechnol. Bioeng. 2003, 81, 316-322. [CrossRef] [PubMed]

24. Rodrigues, L.R.; Banat, I.M.; Teixeira, J.A.; Oliveira, R. Biosurfactants: Potential applications in medicine. J. Antimicrob. Chemother. 2006, 57, 609-618. [CrossRef] [PubMed] 
25. Rodrigues, L.R. Inhibition of bacterial adhesion on medical devices. In Bacterial Adhesion: Biology, Chemistry, and Physics, Series: Advances in Experimental Medicine and Biology; Linke, D., Goldman, A., Eds.; Springer: Berlin, Germany, 2011; Volume 715, pp. 351-367.

26. Jackson, S.A.; Borchert, E.; O'Gara, F.; Dobson, A.D.W. Metagenomics for the discovery of novel biosurfactants of environmental interest from marine ecosystems. Curr. Opin. Biotechnol. 2015, 33, 176-182. [CrossRef] [PubMed]

27. Kiran, G.S.; Sabarathnam, B.; Selvin, J. Biofilm disruption potential of a glycolipid biosurfactant from marine Brevibacterium casei. FEMS Immunol. Med. Microbiol. 2010, 59, 432-438. [CrossRef] [PubMed]

28. Dusane, D.H.; Pawar, V.S.; Nancharaiah, Y.V.; Venugopalan, V.P.; Kumar, A.R.; Zinjarde, S.S. Anti-biofilm potential of a glycolipid surfactant produced by a tropical marine strain of Serratia marcescens. Biofouling 2011, 27, 645-654. [CrossRef] [PubMed]

29. Khopade, A.; Ren, B.; Liu, X.Y.; Mahadik, K.; Zhang, L.; Kokare, C. Production and characterization of biosurfactant from marine Streptomyces species B3. J. Colloid Interface Sci. 2012, 367, 311-318. [CrossRef] [PubMed]

30. Manivasagan, P.; Sivasankar, P.; Venkatesan, J.; Sivakumar, K.; Kim, S.K. Optimization, production and characterization of glycolipid biosurfactant from the marine actinobacterium, Streptomyces sp. MAB36. Bioprocess Biosyst. Eng. 2014, 37, 783-797. [CrossRef] [PubMed]

31. Kiran, G.S.; Hema, T.A.; Gandhimathi, R.; Selvin, J.; Thomas, T.A.; Ravji, T.R.; Natarajaseenivasan, K. Optimization and production of a biosurfactant from the sponge-associated marine fungus Aspergillus ustus MSF3. Colloids Surf. B Biointerfaces 2009, 73, 250-256. [CrossRef] [PubMed]

32. Das, P.; Mukherjee, S.; Sen, R. Antimicrobial potential of a lipopeptide biosurfactant derived from a marine Bacillus circulans. J. Appl. Microbiol. 2008, 104, 1675-1684. [CrossRef] [PubMed]

33. Das, P.; Mukherjee, S.; Sen, R. Antiadhesive action of a marine microbial surfactant. Colloids Surf. B Biointerfaces 2009, 71, 183-186. [CrossRef] [PubMed]

34. Sivapathasekaran, C.; Mukherjee, S.; Samanta, R.; Sen, R. High-performance liquid chromatography purification of biosurfactant isoforms produced by a marine bacterium. Anal. Bioanal. Chem. 2009, 395, 845-854. [CrossRef] [PubMed]

35. Lawrance, A.; Balakrishnan, M.; Joseph, T.C.; Sukumaran, D.P.; Valsalan, V.N.; Gopal, D.; Ramalingam, K. Functional and molecular characterization of a lipopeptide surfactant from the marine sponge-associated eubacteria Bacillus licheniformis NIOT-AMKV06 of Andaman and Nicobar Islands, India. Mar. Pollut. Bull. 2014, 82, 76-85. [CrossRef] [PubMed]

36. Kiran, G.S.; Thomas, T.A.; Selvin, J.; Sabarathnam, B.; Lipton, A.P. Optimization and characterization of a new lipopeptide biosurfactant produced by marine Brevibacterium aureum MSA13 in solid state culture. Bioresour. Technol. 2010, 101, 2389-2396. [CrossRef] [PubMed]

37. Gandhimathi, R.; Kiran, G.S.; Hema, T.A.; Selvin, J.; Raviji, T.R.; Shanmughapriya, S. Production and characterization of lipopeptide biosurfactant by a sponge-associated marine actinomycetes Nocardiopsis alba MSA10. Bioprocess Biosyst. Eng. 2009, 32, 825-835. [CrossRef] [PubMed]

38. Selvin, J.; Shanmughapriya, S.; Gandhimathi, R.; Kiran, G.S.; Ravji, T.R. Optimization and production of novel antimicrobial agents from sponge associated marine actinomycetes Nocardiopsis dassonvillei MAD08. Appl. Microbiol. Biotechnol. 2009, 83, 435-445. [CrossRef] [PubMed]

39. Das, P.; Mukherjee, S.; Sen, R. Substrate dependent production of extracellular biosurfactant by a marine bacterium. Bioresour. Technol. 2009, 100, 1015-1019. [CrossRef] [PubMed]

40. Costa, S.G.V.A.O.; Déziel, E.; Lépine, F. Characterization of rhamnolipid production by Burkholderia glumae. Lett. Appl. Microbiol. 2011, 53, 620-627. [CrossRef] [PubMed]

41. Hosková, M.; Schreiberová, O.; Jezdík, R.; Chudoba, J.; Masák, J.; Sigler, K.; Rezanka, T. Characterization of rhamnolipids produced by non-pathogenic Acinetobacter and Enterobacter bacteria. Bioresour. Technol. 2013, 130, 510-516. [CrossRef] [PubMed]

42. Toribio, J.; Escalante, A.E.; Soberón-Chávez, G. Rhamnolipids: Production in bacteria other than Pseudomonas aeruginosa. Eur. J. Lipid Sci. Technol. 2010, 112, 1082-1087. [CrossRef]

43. Wittgens, A.; Tiso, T.; Arndt, T.T.; Wenk, P.; Hemmerich, J.; Müller, C. Growth independent rhamnolipid production from glucose using the non-pathogenic Pseudomonas putida KT2440. Microb. Cell Fact. 2011, 10, 80. [CrossRef] [PubMed] 
44. Tavares, L.F.D.; Silva, P.M.; Junqueira, M.; Mariano, D.C.O.; Nogueira, F.C.S.; Domont, G.B. Characterization of rhamnolipids produced by wild-type and engineered Burkholderia kururiensis. Appl. Microbiol. Biotechnol. 2013, 97, 1909-1921. [CrossRef] [PubMed]

45. Siegel, R.L.; Miller, K.D.; Jemal, A. Cancer Statistics, 2015. CA Cancer J. Clin. 2015, 65, 5-29. [CrossRef] [PubMed]

46. Bolhassani, A. Cancer chemoprevention by natural carotenoids as an efficient strategy. Anticancer Agents Med. Chem. 2015, 15, 1026-1031. [CrossRef] [PubMed]

47. Cragg, G.M.; Newman, D.J. Plants as a source of anti-cancer agents. J. Ethnopharmacol. 2005, 100, 72-79. [CrossRef] [PubMed]

48. Madadi, N.R.; Zong, H.; Ketkar, A.; Zheng, C.; Penthala, N.R.; Janganati, V.; Bommagani, S.; Eoff, R.L.; Guzmanb, M.L.; Crooks, P.A. Synthesis and evaluation of a series of resveratrol analogues as potent anti-cancer agents that target tubulin. MedChem Comm 2015, 6, 788-794. [CrossRef] [PubMed]

49. Kaur, G.; Verma, N. Nature curing cancer-Review on structural modification studies with natural active compounds having anti-tumor efficiency. Biotechnol. Rep. 2015, 6, 64-78. [CrossRef]

50. Janakiram, N.B.; Mohammed, A.; Rao, C.V. Sea cucumbers metabolites as potent anti-cancer agents. Mar. Drugs 2015, 13, 2909-2923. [CrossRef] [PubMed]

51. Sawadogo, W.R.; Boly, R.; Cerella, C.; Teiten, M.H.; Dicato, M.; Diederich, M. A survey of marine natural compounds and their derivatives with anti-cancer activity reported in 2012. Molecules 2015, 20, 7097-7142. [CrossRef] [PubMed]

52. Niraula, N.P.; Kim, S.H.; Sohng, J.K.; Kim, E.S. Biotechnological doxorubicin production: Pathway and regulation engineering of strains for enhanced production. Appl. Microbiol. Biotechnol. 2010, 87, 1187-1194. [CrossRef] [PubMed]

53. Dey, G.; Bharti, R.; Sen, R.; Mandal, M. Microbial amphiphiles: A class of promising new-generation anticancer agents. Drug. Discov. 2015, 20, 136-146. [CrossRef] [PubMed]

54. Janek, T.; Krasowska, A.; Radwanska, A.; Lukaszewicz, M. Lipopeptide biosurfactant pseudofactin II induced apoptosis of melanoma A375 cells by specific interaction with the plasma membrane. PLoS ONE 2013, 8, e57991. [CrossRef] [PubMed]

55. Sivapathasekaran, C.; Das, P.; Mukherjee, S.; Saravanakumar, J.; Mandal, M.; Sen, R. Marine bacterium derived lipopeptides: Characterization and cytotoxic activity against cancer cell lines. Int. J. Pept. Res. Ther. 2010, 16, 215-222. [CrossRef]

56. Liu, X.; Tao, X.; Zou, A.; Yang, S.; Zhang, L.; Mu, B. Effect of the microbial lipopeptide on tumor cell lines: Apoptosis induced by disturbing the fatty acid composition of cell membrane. Protein Cell 2010, 1, 584-594. [CrossRef] [PubMed]

57. Park, S.Y.; Kim, J.H.; Lee, Y.J.; Lee, S.J.; Kim, Y. Surfactin suppresses TPA-induced breast cancer cell invasion through the inhibition of MMP-9 expression. Int. J. Oncol. 2013, 42, 287-296. [PubMed]

58. Cao, X.H.; Wang, A.H.; Jiao, R.Z.; Wang, C.L.; Mao, D.Z.; Yan, L.; Zeng, B. Surfactin induces apoptosis and G(2)/M arrest in human breast cancer MCF-7 cells through cell cycle factor regulation. Cell Biochem. Biophys. 2009, 55, 163-171. [CrossRef] [PubMed]

59. Kim, S.Y.; Kim, J.Y.; Kim, S.H.; Bae, H.J.; Yi, H.; Yoon, S.H.; Koo, B.S.; Kwon, M.; Cho, J.Y.; Lee, C.E.; Hong, S. Surfactin from Bacillus subtilis displays anti-proliferative effect via apoptosis induction, cell cycle arrest and survival signaling suppression. FEBS Lett. 2007, 581, 865-871. [CrossRef] [PubMed]

60. Das, P.; Sarkar, S.; Mandal, M.; Sen, R. Green surfactant of marine origin exerting a cytotoxic effect on cancer cell lines. RSC Adv. 2015, 5, 53086-53094. [CrossRef]

61. Dey, G.; Bharti, R.; Dhanarajan, G.; Das, S.; Dey, K.K.; Kumar, B.N.P.; Sen, R.; Mandal, M. Marine lipopeptide Iturin A inhibits Akt mediated GSK3 $\beta$ and FoxO3 $\alpha$ signaling and triggers apoptosis in breast cancer. Sci. Rep. 2015, 5, 10316. [CrossRef] [PubMed]

62. Trischman, J.A.; Jensen, P.R.; Fenical, W. Halobacillin-A cytotoxic cyclic acylpeptide of the iturin class produced by a marine Bacillus. Tetrahedron Lett. 1994, 35, 5571-5574. [CrossRef]

63. Zhang, H.L.; Hua, H.M.; Pei, Y.H.; Yao, X.S. Three new cytotoxic cyclic acylpeptides from marine Bacillus sp. Chem. Pharm. Bull. 2004, 52, 1029-1030. [CrossRef] [PubMed]

64. Suyama, T.L.; Gerwick, W.H. Stereospecific total synthesis of somocystinamide A. Org. Lett. 2008, 10, 4449-4452. [CrossRef] [PubMed] 
65. Lee, Y.M.; Dang, H.T.; Hong, J.; Lee, C.O.; Bae, K.S.; Kim, D.K.; Jung, J.H. A cytotoxic lipopeptide from the sponge-derived fungus Aspergillus versicolor. Bull. Korean Chem. Soc. 2010, 31, 205-208. [CrossRef]

66. Lee, Y.M.; Dang, H.T.; Li, J.; Zhang, P.; Hong, J.; Lee, C.O.; Jung, J.H. A cytotoxic fellutamide analogue from the sponge-derived fungus Aspergillus versicolor. Bull. Korean Chem. Soc. 2011, 32, 3817-3820. [CrossRef]

67. Shigemori, H.; Wakuri, S.; Yazawa, K.; Nakamura, T.; Sasaki, T.; Kobayashi, J. Fellutamide-A and fellutamide-B, cytotoxic peptides from a marine fish-possessing fungus Penicillium fellutanum. Tetrahedron 1991, 47, 8529-8534. [CrossRef]

68. Poulsen, T.B. A concise route to the macrocyclic core of the rakicidins. Chem. Commun. (Camb.) 2011, 47, 12837-12839. [CrossRef] [PubMed]

69. Takeuchi, M.I. Rakicidin A effectively induces apoptosis in hypoxia adapted Bcr-Abl positive leukemic cells. Cancer Sci. 2011, 102, 591-596. [CrossRef] [PubMed]

70. Xie, J.J.; Zhou, F.; Li, E.M.; Jiang, H.; Du, Z.P.; Lin, R.; Fang, D.S.; Xu, L.Y. FW523-3, a novel lipopeptide compound, induces apoptosis in cancer cells. Mol. Med. Rep. 2011, 4, 759-763. [PubMed]

71. Yamazaki, Y.; Kunimoto, S.; Ikeda, D. Rakicidin A: A hypoxia-selective cytotoxin. Biol. Pharm. Bull. 2007, 30, 261-265. [CrossRef] [PubMed]

72. Wilson, W.R.; Hay, M.P. Targeting hypoxia in cancer therapy. Nat. Rev. Cancer 2011, 11, 393-410. [CrossRef] [PubMed]

73. Chen, Q.Y.; Liu, Y.; Luesch, H. Systematic chemical mutagenesis identifies a potent novel apratoxin A/E hybrid with improved in vivo antitumor activity. ACS Med. Chem. Lett. 2011, 2, 861-865. [CrossRef] [PubMed]

74. Nunnery, J.K.; Meyers, E.; Gerwick, W.H. Biologically active secondary metabolites from marine cyanobacteria. Curr. Opin. Biotechnol. 2010, 21, 787-793. [CrossRef] [PubMed]

75. Robertson, B.D.; Wengryniuk, S.E.; Coltart, D.M. Asymmetric total synthesis of apratoxin D. Org. Lett. 2012, 14, 5192-5195. [CrossRef] [PubMed]

76. Thornburg, C.C.; Cowley, E.S.; Sikorska, J.; Shaala, L.A.; Ishmael, J.E.; Youssef, D.T.; McPhail, K.L. Apratoxin $\mathrm{H}$ and apratoxin A sulfoxide from the Red Sea cyanobacterium Moorea producens. J. Nat. Prod. 2013, 76, 1781-1788. [CrossRef] [PubMed]

77. Tidgewell, K.; Engene, N.; Byrum, T.; Media, J.; Doi, T.; Valeriote, F.A.; Gerwick, W.H. Evolved diversification of a modular natural product pathway: Apratoxins F and G, two cytotoxic cyclic depsipeptides from a Palmyra collection of Lyngbya bouillonii. ChemBioChem 2010, 11, 1458-1466. [CrossRef] [PubMed]

78. Wrasidlo, W.; Mielgo, A.; Torres, V.A.; Barbero, S.; Stoletov, K.; Suyama, T.L.; Klemke, R.L.; Gerwick, W.H.; Carson, D.A.; Stupack, D.G. The marine lipopeptide somocystinamide A triggers apoptosis via caspase 8. Proc. Natl. Acad. Sci. USA 2008, 105, 2313-2318. [CrossRef] [PubMed]

79. Karanth, N.G.K.; Deo, P.G.; Veenanadig, N.K. Microbial production of biosurfactants and their importance. Curr. Sci. 1999, 77, 116-126.

80. Fuji, N.; Ueda, Y.; Fujiwara, H.; Toh, T.; Yoshimura, T.; Yamagishi, H. Antitumor effect of alphagalactosylceramide (KRN7000) on spontaneous hepatic metastases requires endogenous interleukin 12 in the liver. Clin. Cancer Res. 2000, 6, 3380-3387. [PubMed]

81. Hayakawa, Y.; Takeda, K.; Yagita, H.; Kakuta, S.; Iwakura, Y.; Van Kaer, L.; Saiki, I.; Okumura, K. Critical contribution of IFN-gamma and NK cells, but not perforin-mediated cytotoxicity, to anti-metastatic effect of alpha-galactosylceramide. Eur. J. Immunol. 2001, 31, 1720-1727. [CrossRef]

82. Nakui, M.; Ohta, A.; Sekimoto, M.; Sato, M.; Iwakabe, K.; Yahata, T.; Kitamura, H.; Koda, T.; Kawano, T.; Makuuchi, H.; et al. Potentiation of antitumor effect of NKT cell ligand, alpha-galactosylceramide by combination with IL-12 on lung metastasis of malignant melanoma cells. Clin. Exp. Metastasis 2000, 18, 147-153. [CrossRef] [PubMed]

83. Schneiders, F.L.; Scheper, R.J.; von Blomberg, B.M.; Woltman, A.M.; Janssen, H.L.; van den Eertwegh, A.J.; Verheul, H.M.; de Gruijl, T.D.; van der Vliet, H.J. Clinical experience with alpha-galactosylceramide (KRN7000) in patients with advanced cancer and chronic hepatitis B/C infection. Clin. Immunol. 2011, 140, 130-141. [CrossRef] [PubMed]

84. Farokhi, F.; Wielgosz-Collin, G.; Robic, A.; Debitus, C.; Malleter, M.; Roussakis, C.; Kornprobst, J.M.; Barnathan, G. Antiproliferative activity against human non-small cell lung cancer of two O-alkyl-diglycosylglycerols from the marine sponges Myrmekioderrna dendyi and Trikentrion laeve. Eur. J. Med. Chem. 2012, 49, 406-410. [CrossRef] [PubMed] 
85. Felczykowska, A.; Bloch, S.K.; Nejman-Falenczyk, B.; Baranska, S. Metagenomic approach in the investigation of new bioactive compounds in the marine environment. Acta Biochim. Pol. 2012, 59, 501-505. [PubMed]

86. Kennedy, J.; Flemer, B.; Jackson, S.A.; Lejon, D.P.H.; Morrissey, J.P.; O'Gara, F.; Dobson, A.D.W. Marine metagenomics: New tools for the study and exploitation of marine microbial metabolism. Mar. Drugs 2010, 8, 608-628. [CrossRef] [PubMed]

87. Kennedy, J.; O’Leary, N.D.; Kiran, G.S.; Morrissey, J.P.; O'Gara, F.; Selvin, J.; Dobson, A.D.W. Functional metagenomic strategies for the discovery of novel enzymes and biosurfactants with biotechnological applications from marine ecosystems. J. Appl. Microbiol. 2011, 111, 787-799. [CrossRef] [PubMed]

88. Coughlan, L.M.; Cotter, P.D.; Hill, C.; Alvarez-Ordóñez, A. Biotechnological applications of functional metagenomics in the food and pharmaceutical industries. Front. Microbiol. 2015, 6, 672. [CrossRef] [PubMed]

89. Biver, S.; Steels, S.; Portetelle, D.; Vandenbol, M. Bacillus subtilis as a tool for screening soil metagenomic libraries for antimicrobial activities. J. Microbiol. Biotechnol. 2013, 23, 850-855. [CrossRef] [PubMed]

90. Iqbal, H.A.; Craig, J.W.; Brady, S.F. Antibacterial enzymes from the functional screening of metagenomic libraries hosted in Ralstonia metallidurans. FEMS Microbiol. Lett. 2014, 354, 19-26. [CrossRef] [PubMed]

91. McMahon, M.D.; Guan, C.; Handelsman, J.; Thomas, M.G. Metagenomic analysis of Streptomyces lividans reveals host-dependent functional expression. Appl. Environ. Microbiol. 2012, 78, 3622-3629. [CrossRef] [PubMed]

92. Sen, R. Surfactin: Biosynthesis, genetics and potential applications. Adv. Exp. Med. Biol. 2010, 672, $316-323$. [PubMed]

93. Yang, H.; Yu, H.; Shen, Z. A novel high-throughput and quantitative method based on visible color shifts for screening Bacillus subtilis THY-15 for surfactin production. J. Ind. Microbiol. Biotechnol. 2015, 42, 1139-1147. [CrossRef] [PubMed]

94. Siegmund, I.; Wagner, F. New method for detecting rhamnolipids excreted by Pseudomonas species during growth on mineral agar. Biotechnol. Tech. 1991, 5, 265-268. [CrossRef]

95. Burch, A.Y.; Shimada, B.K.; Browne, P.J.; Lindow, S.E. Novel high-throughput detection method to assess bacterial surfactant production. Appl. Environ. Microbiol. 2010, 76, 5363-5372. [CrossRef] [PubMed]

(C) 2016 by the authors; licensee MDPI, Basel, Switzerland. This article is an open access article distributed under the terms and conditions of the Creative Commons by Attribution (CC-BY) license (http://creativecommons.org/licenses/by/4.0/). 